\title{
Junior High School Here We Come! Evaluating the Effects of a Summer Transition Workshop
}

\author{
Michelle Chamblin \\ Molloy College, New York, USA \\ Email:mchamblin@molloy.edu
}

How to cite this paper: Chamblin, M. (2017) Junior High School Here We Come! Evaluating the Effects of a Summer Transition Workshop. Open Access Library Journal, 4: e3413.

https://doi.org/10.4236/oalib.1103413

Received: January 31, 2017

Accepted: March 6, 2017

Published: March 9, 2017

Copyright (c) 2017 by author and Open Access Library Inc.

This work is licensed under the Creative Commons Attribution International License (CC BY 4.0).

http://creativecommons.org/licenses/by/4.0/

\begin{abstract}
The transition from elementary to middle or junior high school is an event that most youths will experience. Although this is a normal occurrence, some youths face extreme difficulty when making the transition from elementary school to middle or junior high school. Some elementary students experience extreme anxieties as they prepare for the unknown (Akos, 2004). Some studies have found that when students are unable to adjust to junior high school, or unable to transition well, it affects their behavior as well as their academic achievement (Reynolds, 2005). This research investigates a summer transition program and the effectiveness of the program on the academic and social adjustment of 127 incoming junior high school students. Surveys, the students' first marking period grades and attendance as well as participation in sports and schools clubs, post workshop, were analyzed using random samples comparing the data of students that attended the summer transition workshop to students that did not attend. The results of the study revealed no significant difference in academic average $(t=$ $0.721, \mathrm{df}=107, \mathrm{p}<0.72)$ during the first marking period. However, there was a significant difference in attendance $(t=-1.93, \mathrm{df}=107, \mathrm{p}<0.05)$ with the group attending the workshop having less absences during the first marking period. In addition as a result of the summer transition workshop, students reported that they learned effective strategies that they would use and were very confident about beginning the school year. There was only one cited incident of in school suspension for the sample of students that attended the workshop compared to two for the sample that did not attend. The social benefits and gains as a measurable outcome were evident in the results and it can be concluded that the summer transition program was effective in helping students transition to junior high school with in social domains, implying that these types of programs are visceral, effective and necessary.
\end{abstract}

\section{Subject Areas}

Education 


\section{Keywords}

Transition, Adolescent Education, Social-Emotional Learning, Clinically Rich Experiences, Service Learning

\section{Introduction}

The transition from elementary to middle or junior high school is an event that most youths will experience. Although this is a normal occurrence, some youths face extreme difficulty when making the transition from elementary school to middle or junior high school. Some elementary students experience extreme anxieties as they prepare for the unknown (Akos, 2004 [1]). Some studies have found that when students are unable to adjust to junior high school, or unable to transition well, it affects their behavior as well as their academic achievement (Reynolds, 2005 [2]).

As students move to a new environment, with new expectations, they too are undergoing changes. Students face physical and hormonal changes, while the family environment may also be undergoing structural changes to embrace this new phase (Parker, 2013 [3]; Perkins, 1995 [4]; Reynolds 2005 [2]). Thus, this time of flux has become a focal point in research and practice to determine how schools can help students transition well.

The research details best practices for transition and provides guidance on measureable outcomes to be achieved. This We Believe (NMSA, 2010 [5]) states that effective transition programs help students move to a new school and helps the student to become a part of the new school environment. A variety of activities can facilitate this process. An example of these practices listed below is quoted from the article, Transitioning Young Adolescents from Elementary to Middle School; Research Summary by Gilewski \& Nunn (2016 [6]):

1) Touring the new school;

2) Starting a shadow program where fifth graders shadow a sixth grader for the day;

3) Hosting meetings or assemblies and open-house opportunities where the focus is on the differences and similarities between elementary and middle school including the difference in the physical setting and schedules and allow students to ask questions;

4) Hosting parent-to-parent meetings where parents discuss middle school issues and concerns;

5) Sending a welcome letter to students during the summer congratulating them on transitioning to middle school and including dates of upcoming transition events;

6) Having new students come to school a day before returning students to get information, practice routines, and meet teachers;

7) Developing activities where students can socialize prior, during, and after transitions, such as community service projects, clubs, and intermural sports. 
The summation of the programs and best practices found in the research on transition indicates that programs need to have opportunities for students from elementary school to shadow middle schoolers, parents need to have opportunities to tour the school, there needs to be an open house and lastly, students and parents need opportunities to ask questions (Gilewski \& Nunn 2016 [6]). In other words, it can be concluded that a good transition program addresses concerns and provides an opportunity for the student to prepare for the shift in academic demands, social network, school environment physicality and last but not least, an opportunity to speak with student currently enrolled in the school.

\section{Purpose of Study}

In this study, a Summer Transition Workshop was created and implemented to determine the impact of the workshop on student outcomes. The following questions were asked:

1) Will the transition program help prepare students academically?

2) Will the transition program impact the students socially?

3) Will the transition program aid in the student engagement?

\section{The Experiment}

\subsection{Participating School}

Valley Stream Memorial High School is located in Valley Stream New York. It is a suburban community which is multi ethnic and serves a very diverse student population. Memorial is one of the few Junior High Schools that serve students in grades 7, 8 and 9. Students transition from elementary school in grade 6 to the junior high school in grade 7 . This difference in configuration causes unique promise and challenges for the school in that it needs to embrace both a middle school and high school identity.

In a school wide reflective practice as a result of applying for and participation in the Schools to Watch, Invitational Schools and National schools of Character programs, administrators sought to institute programs that cultivated a sense of belong and respect which they described as the overall tone of the school; a place where everyone counts and is a community. The researcher, as a professor of graduate students in education, determined this was an opportunity for a service learning project and graduate students to work directly with be more aware the social domains of schooling including the social-emotional aspect. The researcher partnered with this school to create a summer transition workshop that would benefits the incoming students and provide a clinically rich experience for the graduate students.

The adolescent students that participated in this study were in coming $7^{\text {th }}$ graders, zoned to attend the school. The students participated in the transition workshop during the summer post $6^{\text {th }}$ grade graduation.

\subsection{Procedure}

\subsubsection{Student Invitation}

All incoming $7^{\text {th }}$ graders received a letter from the principal of Memorial Junior 
High School inviting them to participate in a Summer Transition Workshop to convene at the Junior high school during the months of July and August twice a week for three weeks. The students were invited to participate in a total of six sessions which ran from 9:30 am to 11:45 am. Three hundred and fifty students from four elementary schools were zoned to enter as $7^{\text {th }}$ graders for September. The program was offered free of charge as a joint venture between the school district and Molloy College, located in Rockville Centre, New York.

\subsubsection{Curriculum Writing and Creating the Workshop}

Although the Summer Transition Workshop was scheduled for the summer of 2016, the creation of the curriculum and program planning began in September of 2015. The researcher investigated the research to locate curriculum for transition programs and found none. Suggestions about what should be a part of a transition program were used to create the foundation of the program. However, the school did have transition activities which were in agreement with what was found in the literature. Therefore, the transition program to be created was much more extensive and comprehensive than what was found in the literature and in practice.

After this initial step, school personnel was surveyed to gain their perspective of the problematic areas consistently faced by incoming $7^{\text {th }}$ grade students. To gain a broader view, a focus group of $8^{\text {th }}$ graders were interviewed. The results of the interview would help to depict their experiences in the transition from elementary school to Memorial Junior High School and determine how they had been prepared; also, whether that preparation was deemed valuable and/or useful.

Administration and staff were asked similar questions to gather the transition issues they observed outside of the perspective of teachers and counselors. Feedback from each group was collected and analyzed. A summation of the findings is presented in the proceeding paragraphs.

\subsubsection{Survey Feedback - $7^{\text {th }}$ Grade Teachers and Guidance Counselors}

Feedback indicated that following areas were in need of being addressed: organization strategies, planning and study skills and knowing the resources in the building which included knowing what to access. For example, students access assistance from an adult or guidance counselor. Incoming students seem to be less capable or aware of self-advocacy skills. This is important when interacting with nine teachers a day instead of just one as they had done so in elementary school. Other concerns from teachers and guidance counselors were mostly academic in nature.

\subsubsection{Focus Group Feedback-Current $8^{\text {th }}$ Graders}

A focused group of $8^{\text {th }}$ graders were interviewed to ask about their transition to Memorial Junior High School. The students were asked to complete the phrase, "the one thing I wished someone would have told me about Memorial is..." A compilation of the responses revealed that the students did not believe that the information they received in elementary school about middle school was accu- 
rate. The preparation they received from the elementary school was rule based and more of a warning of what would and would not be accepted in the area of behavior. Most agreed that their most valued transition experience began when they were physically in the building at the tour and open house.

Students commented that there was too much conversation about bullying and the negative experiences they might have. They stated that it was difficult to appreciate transition activities in elementary school because Junior High School seems like a completely different world.

The responses to the questions stating one thing about Memorial that they wish someone would have told them were the positive aspects of the school such as the number of teams and clubs they could become involved with and that due to there are people in the building who will help. No matter your interest, students responded that there was something for everyone and this widened their social networks which they felt was a contributing factor to a decrease in cliques.

Additional responses included that after the first few weeks of school is very difficult and transitioning into the school becomes easier if you join a club. Other responses included the need to know that there are certain behaviors that are necessary to get along with particular teachers. Hidden curriculum information which is usually shared peer to peer was information they wished they had, especially for those who did not have older siblings that attended the school. Increased opportunities to learn this information, in their opinion, would have been most helpful.

\subsubsection{Feedback: Administrators and Staff}

Administrators were surveyed and the results indicated that incoming students most often had difficulties with the physical plant of the building and changes in social groups. Issues such as the effects of social media and acts that affect the student in school as well as out of school become a new reality with grave consequences.

Staff indicated the need for incoming students to be organized, hand in forms on time and attend to the shift in responsibility. Staff also indicated the importance of being on time to school.

\section{The Curriculum}

The survey information and feedback was used to create a curriculum for the three week Summer Transition Workshop. In addition, the researcher would incorporate evidenced based teaching practices to address the needs expressed by teachers, administration students and staff in the curriculum created. The lessons created for the workshop would be hands-on, engaging and interactive. One criticism expressed by the $8^{\text {th }}$ grade focus group students was that the transition activities were usually lecture based by an adult and the opportunities to do things in the building, such as figuring out their lockers and walking around on the tour seemed more memorable. Therefore, the task called for the creation of a curriculum which had memorable components and many active learning activities. 
One evidenced based practice used to create the lesson was learning strategies based on the Strategic Intervention Model (Dreshler, Ellis, Lenz, 1996 [7]; Bulgren, Schumaker \& Dreshler 1994 [8]; Dreshler \& Shumaker 1988 [9]; Hock, Dreshler \& Shumaker 1993 [10]) Learning strategies are designed so that students can think through a problem and select a way to plan and execute steps to address the problem (Chamblin, 2016 [11]). This seemed to equate well with the problems expressed by the teachers. Using the some of these strategies, the researcher created lessons to address organizational skills, study skills, and communication skills. Every lesson employed a mnemonic device to help with student retention and activities which would engage auditory, visual, tactile and kinesthetic learners.

A curriculum consisting of eleven lessons was created to address the aforementioned areas; organizational, study, and communication skills. Included in the curriculum was a mock day in which students moved around the building for a nine period day schedule with each period lasting five minutes. A question and answer session with for the incoming $7^{\text {th }}$ graders and current $8^{\text {th }}$ grade students was also a part of the curriculum.

\section{Implementation}

This researcher modeled each lesson of the curriculum to Graduate Students in the Division of Education who in turn key fashion conducted the sessions with the incoming $7^{\text {th }}$ grade students during the month of July and August. The Summer Transition Workshop consisted of two Graduate Students co-teaching groups of 15 to 18 students. Classes began at 9:30 and ended at 11:45 on Tuesdays and Thursdays. There were a total of six sessions. Students were invited to attend all six sessions.

\section{Results}

Three hundred and fifty students were invited to attend the Summer Transitions Workshop. Of that number Two hundred registered. One hundred and twenty seven students attended consistently at least 5 out of the six sessions.

To analyze the impact of the program and address the research questions data was collected during and after the program. The collection consisted of descriptive and inferential statistics.

\subsection{Student Exit Survey}

On the last session of the workshop, 68 students who had attended all the sessions, were given an exit survey which asked which strategy they liked the best, if they would use the strategy and as a result of the workshop, how confident they felt about beginning the school year. Table 1 shows that the Blinder Blunder and Communication for Resolving Conflicts was selected at a higher frequency that the other strategies. The Binder Blunder was a strategic lesson created by the researcher on how to organize a binder. Resolving Conflicts for Communication was also created by the researcher. Students were presented with scenarios and 
communication strategies they could use when in a difficult situation in school.

Table 2 shows that of the sixty eight students that took the survey forty eight would definitely use the strategies learned in the workshop and twenty two might. No student responded that he/she would definitely not use any of the strategies learned.

As a result of the workshop Sixty seven out of the sixty eight students reported that they felt confident or somewhat confident to begin the school year, as exhibited in Table 3.

\subsection{Statistical Analysis}

During the first marking period after the transition workshop, a random sample of students that attended the workshop was compared to a random sample of students that did not attend the workshop.

A total of one hundred and nine students were randomly selected. Sixty one attended the transition workshop and forty eight did not (Table 4). Of the one

Table 1. Survey question 1: The strategy that I liked the best was....

\begin{tabular}{cc}
\hline Strategy Name/Lesson & Number of Responses \\
\hline A. Binder Blunder & 14 \\
B. Note Taking & 5 \\
C. Visual Imagery & 0 \\
D. Paraphrasing & 7 \\
E. Test Taking & 3 \\
F. Word Identification & 1 \\
G. Self-Questioning & 0 \\
H. Assignment Completion & 7 \\
I. Error Monitoring & 4 \\
J. Peg Word & 1 \\
M. No Response & 14 \\
K. Resolving Conflicts with Clear Communication & 2 \\
\hline
\end{tabular}

Table 2. Survey question 2: I will use the strategies I learned during the school year.

\begin{tabular}{cc} 
Response Selection & Number of Responses \\
\hline A. Definitely & 46 \\
B. Maybe & 22 \\
C. Not at all & 0
\end{tabular}

Table 3. Survey question 3: As a result of attending this summer workshop, I feel....

\begin{tabular}{cc}
\hline Response Selection & Number of Responses \\
\hline A. Very confident to begin the school year at Memorial & 42 \\
B. Somewhat confident to begin the school year at Memorial & 26 \\
C. Do not feel confident to begin the school year at Memorial & 1 \\
\hline
\end{tabular}


hundred and nine students, 26.6 percent were accelerated or gifted students. 58.7 percent were general education students and 14.7 percent were students with disabilities receiving some form of special education service (Table 5). Data table shows that 55 percent of the sample, female and 54 percent male (Table 6). The random samples were a balanced reflection of the school population and in agreement by ratio to the student body.

The means of the number of absences and academic averages for the first marking period between both groups were compared (Table 4). Attendance was used as a label for the number of absences and for the students that attended the workshop; they had a mean average of 0.5 absence for the first marking period. For the students that did not attend the workshop, there was a mean of $1 \mathrm{ab}$ sence for the first marking period. In the area of academic average, the group that attended the summer workshop obtained an 86.9 compared to 86.4 for those that did not attend the summer workshop. When comparing the means between groups in the area of academic average and absences, the results were very close. To dig deeper to determine if there was a significant difference between the means and get a fuller inspection of the data, a t-test was applied.

An independent sample t-test was conducted (Table 7) to examine whether there was a significant difference between students that attended the Summer

Table 4. Mean differences in attendance (number of absences) and academic average between samples groups.

\begin{tabular}{cccccc}
\hline & Program & $\mathrm{N}$ & Mean & Std. Deviation & Std. Error Mean \\
\hline \multirow{2}{*}{ Attendance } & Yes & 61 & 0.5410 & 1.02589 & 0.13135 \\
& No & 48 & 1.0208 & 1.55042 & 0.22378 \\
\multirow{3}{*}{ Average } & Yes & 61 & 86.9446 & 7.77082 & 0.99495 \\
& No & 48 & 86.4446 & 6.97009 & 1.00605 \\
\hline
\end{tabular}

Table 5. Student sample data disaggregated by class assignment; accelerated (gifted students), regents (general education students) and special ed. (students with disabilities).

\begin{tabular}{cccccc}
\hline \multicolumn{5}{c}{ Class } \\
\hline & Frequency & Percent & Valid Percent & Cumulative Percent \\
\hline \multirow{4}{*}{ Valid } & Accelerated & 29 & 26.6 & 26.6 & 26.6 \\
& Regents & 64 & 58.7 & 58.7 & 85.3 \\
& Special Ed & 16 & 14.7 & 14.7 & 100.0 \\
& Total & 109 & 100.0 & 100.0 & \\
\hline
\end{tabular}

Table 6. Student sample data disaggregated by gender.

\begin{tabular}{cccccc}
\hline \multicolumn{5}{c}{ Gender } \\
\hline \multirow{4}{*}{ Valid } & Fequale & 55 & 50.5 & 50.5 & Cumulative Percent \\
& Male & 54 & 49.5 & 49.5 & 50.5 \\
& Total & 109 & 100.0 & 100.0 & 100.0 \\
& & & & & \\
\hline
\end{tabular}


Transitions Workshop and students that did not attend the workshop in relation to their first marking period grade average and attendance/absences for the marking period. The test revealed there was no significant difference in average $(\mathrm{t}=0.721, \mathrm{df}=107, \mathrm{p}<0.728)$. There was a significant difference in attendance $(\mathrm{t}=-1.93, \mathrm{df}=107, \mathrm{p}<0.054)$ with the group attending the workshop having less absences through deeper inspection of the data set than those that did not attend the workshop.

\subsection{Participation in Clubs}

Of the random samples drawn, for those that participated in the summer transition workshop, eighty nine percent were in one or more clubs. Of those who did not attend the workshop sixty three percent were in one club or more. In addition, for those that attended the workshop, the types of clubs participated were very diversified with twenty five percent being in sports clubs and sixty four percent attending other clubs including but not limited to: Newspaper Club, Game Club and Step Club. Whereas, those who did not attend the workshop had a forty four percent participation rate in sports clubs and nineteen percent participation in other clubs. This information is displayed in Table 8.

\subsection{In School Suspension}

Of the random sample, one student was assigned to in school suspension. To the contrary of the sample of students who did not attend the transition workshop, two students were assigned in school suspension.

Table 7. Independent $\mathrm{T}$ test comparing the absences (attendance) and the academic averages between sample groups.

\begin{tabular}{|c|c|c|c|c|c|c|c|}
\hline \multicolumn{8}{|c|}{ Independent Samples Test } \\
\hline & & \multicolumn{2}{|c|}{ Levene's Test for Equality of Variances } & \multicolumn{4}{|c|}{ t-test for Equality of Means } \\
\hline \multirow{2}{*}{ Attendance } & Equal variances assumed & 3.173 & 0.078 & -1.938 & 107 & 0.054 & -0.47985 \\
\hline & Equal variances not assumed & & & -1.849 & 77.736 & 0.068 & -0.47985 \\
\hline \multirow{2}{*}{ Average } & Equal variances assumed & 0.128 & 0.721 & 0.349 & 107 & 0.728 & 0.50001 \\
\hline & Equal variances not assumed & & & 0.353 & 105.124 & 0.725 & 0.50001 \\
\hline
\end{tabular}

Table 8. Student sample data of participation in sports and clubs disaggregated by students that attended and did not attend the summer workshop.

\begin{tabular}{|c|c|c|c|c|c|c|}
\hline & $\begin{array}{l}\text { Number of } \\
\text { students in } \\
\text { sample }\end{array}$ & $\begin{array}{c}\text { Number } \\
\text { Participating in } \\
\text { Traditional Sports }\end{array}$ & $\begin{array}{c}\text { Number Participating } \\
\text { in Traditional Sports } \\
\text { converted to } \\
\text { Percentage }\end{array}$ & $\begin{array}{l}\text { Number Participating } \\
\text { in Non-Sports Clubs }\end{array}$ & $\begin{array}{c}\text { Number Participating } \\
\text { in non-Sports Clubs } \\
\text { converted to } \\
\text { Percentage }\end{array}$ & $\begin{array}{l}\text { Total Percent } \\
\text { Participating in Sports } \\
\text { and Non-Sports Clubs }\end{array}$ \\
\hline $\begin{array}{c}\text { Attended } \\
\text { Summer Transitions } \\
\text { Workshop }\end{array}$ & 61 & 15 & $25 \%$ & 39 & $65 \%$ & $89 \%$ \\
\hline $\begin{array}{c}\text { Did Not Attend } \\
\text { Summer Transition } \\
\text { Workshop }\end{array}$ & 48 & 21 & $44 \%$ & 9 & $19 \%$ & $63 \%$ \\
\hline
\end{tabular}




\section{Conclusions}

Although there was not a statistical difference in averages from those that attended the workshop and those that did not the data illustrates the importance of using a variety of indicators. These data illustrate the impact in the areas of social domain which are important in creating effective transition programs (Cauley \& Jovanovich 2006 [12]).

Those that attended the workshop had a significant difference in attendance meaning that they had fewer absences during the first marking period. This is also significant considering the average mean of absences for the sample was very low.

The results from the survey indicate that participation in the transition program helped students feel more confident about beginning the school year. As per their exit survey, they had a strategy that they could use and would use. Students had the opportunity to speak with an enrolled student and move around the building during the sessions. On the mock day the students experienced what it would be like to go through a bell scheduled day; a very valuable experience.

The data demonstrate that students who attended the program were more likely to participate in clubs and not just sports clubs. In fact, a variety of clubs were selected and joined by those students. This important finding may indicate that students who attended the summer transition program were encouraged to be a part of the school as an active participator. The experience of the transition workshop may have been instrumental in making students feel welcomed, forging an initial sense of belonging.

There wasn't a statistical difference in academic average during the first marking period between the student groups. However, the data show that the transition program may have impacted the students in social domains, as mentioned and this includes engagement, belonging and having the perception of being more prepared.

Informal feedback from parents indicated that they felt the program helped the students and they reported witnessing their children using some of the strategies learned in the workshop at home in regards to organization and study skills.

\section{Limitations of Study}

As with this type of research there are some limitations. In trying to establish a causal or functional relationship, there are too many confounding variables that are out of the control and scope of the study. For example there is a variability of parenting style, personality and even having an older sibling that attended the school that could influence transition.

The program occurred in the summer and attendance was not constant for the group. Absences during the summer were allowable due to vacations so this caused lots of variability. The implementation of the schedule was one of the items that needed to be address for future workshops. Also, there were technol- 
ogy and environmental issues such as days when it was extremely hot and days when technology wouldn't cooperate that caused changes in the teaching format and teacher, student ratio. These types of incidences are typical in the education setting but do prose as limitations in formal research.

\section{Future Directions}

As stated in This We Believe (NMSA, 2010) effective transition programs help students move to a new school and helps the student to become a part of the new school environment. This is done because we value the students and acknowledge the social needs during this very difficult time. The Summer Transition Workshop may have helped incoming $7^{\text {th }}$ graders become a part of the Memorial Junior High School. There are various transition activities and supports within the school and this type of program brings added benefits. Based on the feedback from students, teachers and parents, the program will be revised and updated with a greater focus on social skill strategies and team building activities for the next scheduled Summer Transition Workshop.

\section{References}

[1] Akos, P. (2004) Advice and Student Agency in the Transition to Middle School. Research in Middle Level Education, 27, 1-11. https://doi.org/10.1080/19404476.2004.11658169

[2] Reynolds, K. (2005) The Fourth Grade Experience: Insights toward the Transition to Middle School. http://eric.ed.gov/?id=ED491409

[3] Parker, A.K. (2013) Understanding and Supporting Young Adolescents during the Transition into Middle School. In: Andrews, P.G., Ed., Research to Guide Practice in Middle Grades Education, Association for Middle Level Education, Westerville, 495-510.

[4] Perkins, P.I. (1995) Elementary to Middle School: Planning for Transition. Clearing House, 68, 171-173. https://doi.org/10.1080/00098655.1995.9957223

[5] National Middle School Association (2010) This We Believe: Keys to Educating Young Adolescents. Westerville.

[6] Gilewski, C. and Nunn, M. (2016) Transitioning Young Adolescents from Elementary School. http://www.amle.org/

[7] Deshler, D., Ellis, E. and Lennz, B. (1996) Teaching Adolescents with Learning Disabilities. Love Publishing Co., Denver.

[8] Bulgren, J.A., Schumaker, J.B. and Dressler, D.D. (1995) Effectiveness of a Concept Teaching Routine in Enhancing the Performance of LD Students in SecondaryLevel Mainstream Classes. Learning Disability Quarterly, 11, 3-17. https://doi.org/10.2307/1511034

[9] Dreshler, D.D. and Schumaker, J.B. (1988) An Instructional Model for Teaching Students How to Learn. In: Graden, J.L., Zins, J.E. and Curtis, M.J., Eds., Alternative Educational Delivery Systems. Enhancing Instructional Options for All Students, NASP, Washington DC, 391-411.

[10] Hocks, M.F., Dreshler, D.D. and Schumaker, J.B. (1993) Learning Strategy Instruction for at Risk and Learning Disabled Adults: The Development of Strategic Learners through Apprenticeship. Preventing School Failure, 38, 43-49. https://doi.org/10.1080/1045988X.1993.9944294 
[11] Chamblin, M. (2016) Seeing through a Different Lens: Can Applying a Learning Strategy to Video Viewing Deepen the Self-Reflection of pre Service Teachers. http://www.oalib.com/paper/5277793\#.WIkHMGeQzcs

[12] Cauley, K. and Jovanovich, D. (2006) Developing an Effective Transition Program for Students Entering Middle School or High School. Clearing House, 80, 15-25. https://doi.org/10.3200/TCHS.80.1.15-25

Submit or recommend next manuscript to OALib Journal and we will provide best service for you:

- Publication frequency: Monthly

- 9 subject areas of science, technology and medicine

- Fair and rigorous peer-review system

- Fast publication process

- Article promotion in various social networking sites (LinkedIn, Facebook, Twitter, etc.)

- Maximum dissemination of your research work

Submit Your Paper Online: Click Here to Submit

Or Contact service@oalib.com 